\title{
Romania's Railway Development 1950-1989: Changing Priorities for Socialist Construction
}

\section{Turnock, David ${ }^{1}$}

\begin{abstract}
There was considerable development in the communist period when the railway was the principal means of transport to support a programme of rapid industrialisation. New construction took place in many areas, but mainly to open up raw material sources rather than improve the connectivity of the system through additional routes across the Carpathians. Great efforts were also made to widen track and electrify the heavily-used lines along with modernisation of both motive power and rolling stock to sustain economic growth based on a network of key centres with limited spread to backward areas. Many new projects remain outstanding despite some transfer from road to rail transport during the 1980 and significant future completions are now unlikely. The paper also reviews the expansion of narrow-gauge forestry lines that were essential in the early post-war years before road transport was developed. The Vâlcea case shows how rail systems were extended across challenging terrain and although they were almost all closed by 1965 they form a significant part of Romania's railway age.
\end{abstract}

Key words: Reilway development, Romania and Transport

\section{David Turnock}

Geography Department, University of Leicester, Leicester LE1 7RH, United Kingdom, dt8@leicester.ac.uk

\section{Introduction}

In previous papers the author has examined the developing railway system in Romania - especially the state railway Căile Ferate Române (CFR) - as a process fundamental for the country's modernisation but also one that is closely tied up with a varied topography - with implications for route selection - and politically-inspired evaluation of economic and strategic concerns in changing international contexts (Turnock, 1999, 2004). While much of the country is well-adapted for railway construction there is also much evidence of 'heroic' achievement in the sense of major resource allocation, engineering capacity and labour input by a developing country with limited mechanical support. Mountain lines have required considerable tunnelling and bridge-building, while hilly regions are often prone to instability through landslides and the lowlands have also posed severe challenges through major rivers with variable discharge and constant risk of flood damage (Plate 1). Since the communist era is often seen as eminently voluntaristic in the sense of an ideologically-committed leadership (in the Soviet mould) motivating nations to reach the ultimate goals of human endeavour it is perhaps appropriate to consider Romania's progress in railway development against the ethos of what is now seen as a highly-controversial phase of its modern history.

Although industry was always the priority under communism, transport was fundamental for growth in manufacturing and investment levels were always substantial, although the global investment figures (hovering around ten percent of total investment) do not allow the railway interest to be separated from other transport modes that attracted spending on such projects as the Bucharest-Piteşti motorway, Bucharest-Otopeni airport and the Danube-Black Sea Canal to Constanța. However the railway was always of prime importance and Romanian writers gave prominence to statements by Soviet leaders including Lenin's advocacy of railways to link agriculture with industry and the countryside with the town (Soran, 1953).
Due prominence was also given to Stalin's pronouncement of 1935 that a well-organised railway system was an essential pre-requisite for economic development, linking complementary regions and resources (Rădoi, 1954). Of course the system was already extensive with a network of $9,900 \mathrm{kms}$ in 1938 rising to 10,853 in 1950 and 11,348 in 1990. But since there were many uncompleted projects it seemed likely that the substantial achievements of earlier years would be exceeded. The first postwar communist leader Gh.Gheorghiu-Dej was a former railway worker, 'exiled' from Bucharest to the north Transylvania town of Dej (duly incorporated into his surname!) in a bid to curb his union activity. However despite an initial surge of activity after the communists came to power, total network length increased by only $3.0 \%$ from $11,012 \mathrm{kms}$ in 1970 and 11,348 in 1990.

\section{Expansion of the network}

The first two decades of communist rule effectively abandoned ambitious programmes of railway network development inherited from the inter-war years. The government was initially anxious to continue the major programme of public works and the First Five Year Plan envisaged some $300 \mathrm{kms}$. of new railway. It was not revealed just which lines were involved but the only achievements were improved links with Bulgaria (through the CalafatVidin ferry of 1950 and the Giurgiu-Ruse 'Friendship Bridge' of 1954) and short lines in 1951 (a) from Piatra Neamț to Bicaz (a base for future activity in cement production and hydropower development) and (b) to Capul Midia from Constanța-Palas and Dorobantu (in connection with Black Sea port facilities) (Figure 1). It is possible that the Curtea de Argeş-Râmnicu Vâlcea and Întorsura Buzăului-Nehoiaşu lines were planned in order to reduce pressure on the overloaded Ploieşti-Predeal-Braşov route. But Peaha (1965) states that while some outstanding main line projects were reconsidered no work was undertaken at this time. Another priority could have been the early completion of the Deva-Brad line (where the Stoeneşti-Dealul Fetii sec- 
tion had been outstanding since 1944) and the plugging of a further gap between Vârfuri and Vaşcău to complete the strategic axis between Oradea and Craiova. Another possibility was a direct central railway from Cluj-Napoca to Târgu Mureş and Ciceu, for reports of 1948-9 referred to activity between Apahida near Cluj and even suggested that the line was almost ready. This appears to have been a gross exaggeration but it is documented that the Odorhei-Ciceu line - proposed by local interests during 1925-30 - was studied in 1950 and implemented in 1952. However, in view of the difficulties encountered through Vlăhița the project was given up in favour of others (unspecified) already under way. Subsequent studies produced four variants for an easily-graded main line: a 60 $\mathrm{km}$ route with five tunnels $(2.24 \mathrm{kms})$ or six tunnels of $(7.73 \mathrm{kms})$; or a shorter $50 \mathrm{~km}$ route with three tunnels $(19.95 \mathrm{kms})$ or four (22.59 kms) (Iordănescu and Georgescu 1986). There was also the Odorhei-Voslobeni variant via Sicaş Pass: a route of $59 \mathrm{kms}$ with 14 tunnels $(6.15 \mathrm{kms})$. Overall however the brutal forced labour regime unleashed by the communists gave priority to the Danube-Black Sea Canal (CernavodăConstanța) to provide a Romanian link with ocean shipping at a time when the Soviets controlled the key delta routes.

THE NEW COURSE after Stalin's death in 1953 brought a scaling-down of extravagant public works until adequate engineering capacities were available (e.g. in the hydropower domain). When GheorghiuDej addressed railway workers in 1953 he made no mention of new construction and his long speech was concerned entirely with inefficiency (that nationalisation was meant to overcome) evident through excessive shunting and re-marshalling of freight trains, slow unloading, insufficient full-wagon loads and simultaneous movement of empty wagons between yards in both directions! With substantial skilledstaff shortages, aggravated by poor training, Romania's 'ceferiști' (the name used for railwaymen based on the acronym CFR) were exhorted follow the working methods "ale lucrărătorilor de căle ferata stahanovişti din Uniunea Sovietică” (Soran, 1953). Given this breath of realism there was a greater readiness to make the fullest use of the network available. Indeed for the next decade or so standard gauge railway building was restricted to three lines required to open up lignite fields in Oltenia (Târgu Jiu-Rovinari in 1964 and StrehaiaMotru in 1966) and in Bihor (MarghitaVoivozi in 1957); short branches to factories (mainly Galați-Smârdan in 1966, for a huge metallurgical project) and the direct line of $42 \mathrm{kms}$ between Ițcani (Suceava) and Păltinoasa (1964) to replace the earlier route of the same length through Cac-

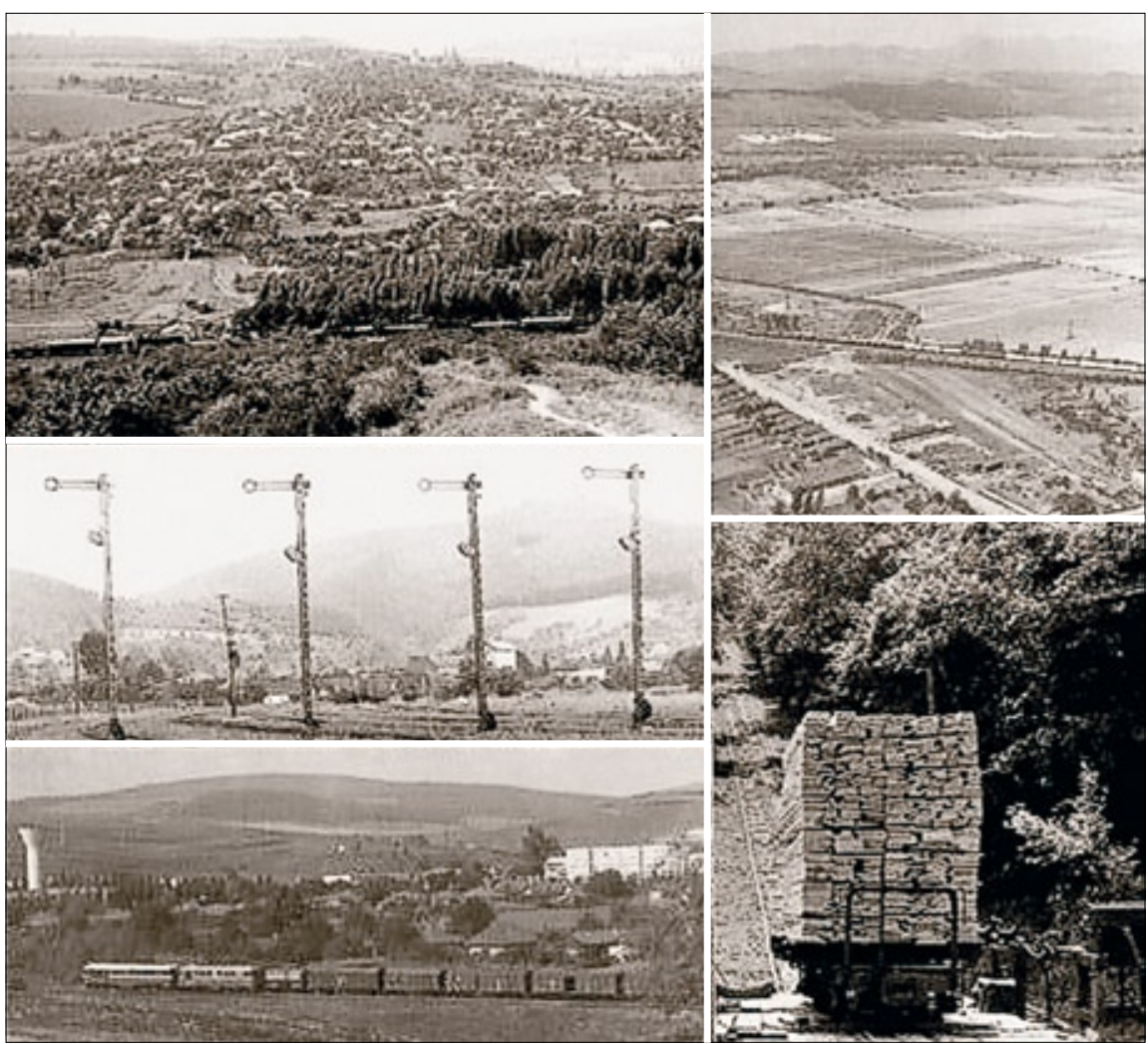

Plate 1 Railway landscapes: a heavy freight moves through the southern suburbs of laşi on the edge of the Moldavian Plateau coming from the Vaslui direction (top left); a row of semaphore signals at Ciucea (between Cluj-Napoca and Oradea) with the forested Carpathians behind (centre left); a heavy freight moves westwards out of Cluj-Napoca with a 4,00ohp diesel-electric locomotive piloting one the older 2,10ohp types (bottom left); another freight train heading westwards along the Mureş corridor at Deva with the Western Carpathians in the distance (top right); and in a Carpathian forest: a wagonload of sawn timber arrives at the foot of the inclined plane on the Comandău-Covasna forest railway.

ica that involved sharp curves and a difficult bank at Strigoaia. The old route was acceptable in the context of the original 'Bukowiner Lokalbahn' of 1888 (branching from the Suceava-Cernăuți main line at Dărmăneşti) but was not appropriate for the Cluj-Iaşi inter-city created by the extension from Vatra Dornei to Ilva Mică in northern Transylvania in 1938. Construction started during $1951-5$ but was interrupted for financial considerations and resumed 1959-64. There was a single tunnel (Lucăceşti: 426 m, finished in 1961) and six viaducts with a total length of $0.69 \mathrm{~km}$.

More ambitious construction became necessary in connection with hydropower and navigation schemes, most notably at the Iron Gates where a $24 \mathrm{~km}$ CoramnicValea Cladovei diversion was required between Drobeta-Turnu Severin and Topleț), with ten tunnels (combined length of 1.60 $\mathrm{kms})$ and 21 viaducts $(1.85 \mathrm{kms})$ required on account of the Iron Gates hydropower scheme (1971). A study of sites during 195760 revealed the potential immediately above Turnu Severin (Iron Gates I) and another further downstream (Iron Gates II) that did not have any implications for the railway network. After studies identifying the site (1957-60) and compiling detailed plans (1960-3), construction of a new single-track railway at a higher level through Iron Gates
I began in 1964 and was ready in 1968, in good time for the completion of the hydro scheme in 1971 (whereupon the original line through the gorge was flooded). Modifications were also required as a result of the Olt valley hydropower complex over a lengthy period extending from 1977 to 1988 , particularly between Călimăneşti and Lotru. With the additional complication of double track, a substantial amount of tunnelling was required at Cârligu, Cozia, Lotrioara and Turnu where a total of 10 single-bore tunnels extended cumulatively over $7.34 \mathrm{kms}$. However, further effort was needed to cope with the expansion of extractive industries. Stone quarrying for new cement factories required the Amaradia-Bârseşti line (1971) and another from Câmpulung to Argeşel (1977), including the $245 \mathrm{~m}$ Costita tunnel. But the expansion of lignite mining brought a succession of new lines in Oltenia: FiliaşiTurceni-Rogojelu-Rovinari (1977); TurceniDragoteşti (1982); Târgu Cărbuneşti-Albeni (1983); Băbeni-Berbeşti-Alunu (1986); Albeni-Calnic (1987); and Calnic-Seciuri (1989). There was also a short extension in the Jiu valley (mainly a shaft mining area) from Lupeni to Bărbăteni in 1986. Most of these lines did not require substantial engineering work, but access to Alunu and Seciuri across of succession of valleys and ridges required considerable tunnelling: four 


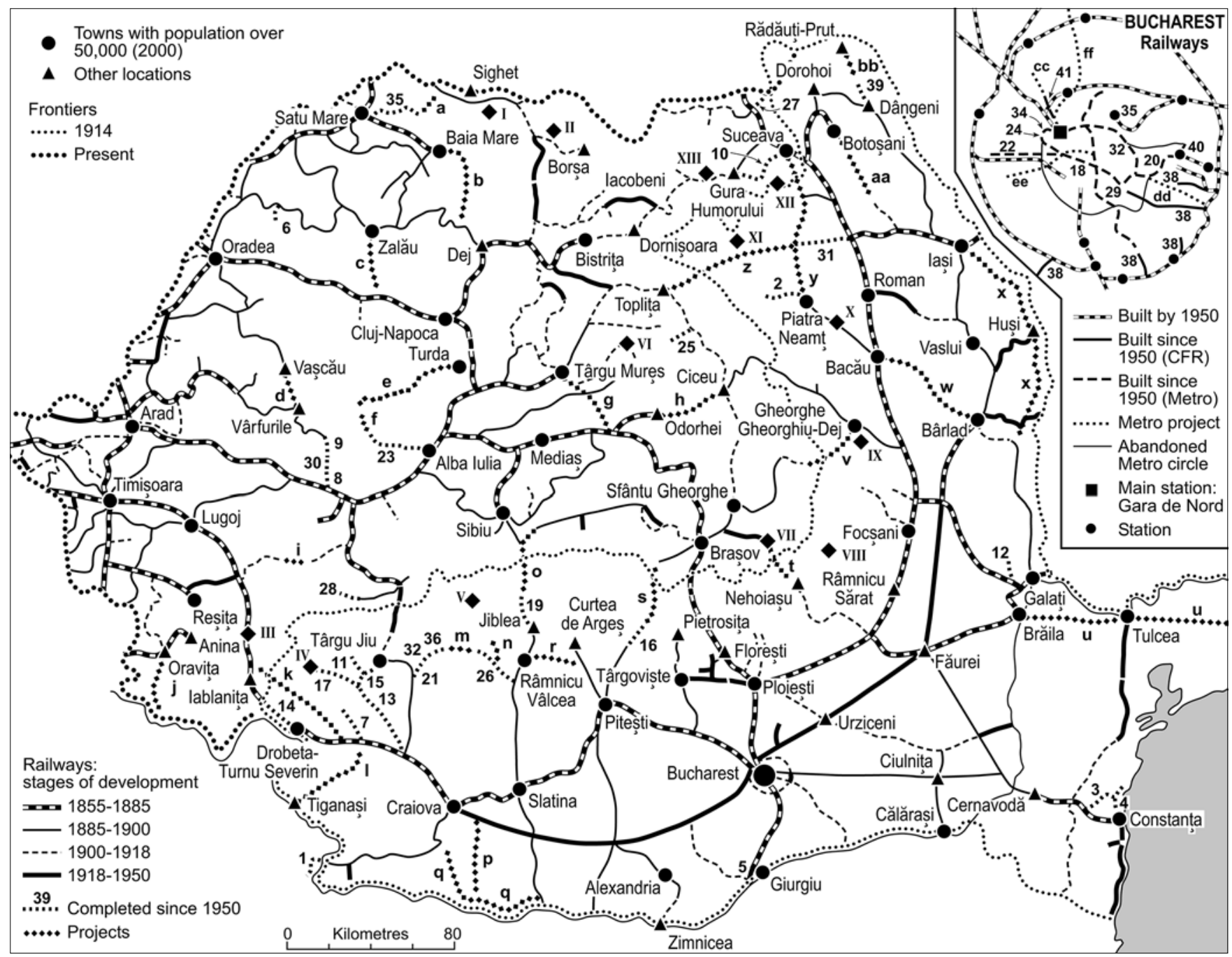

Figure 1 Network development, highlighting new construction since 1950 and outstanding projects

LIST OF NEW LINES Shown by serial numbers $1,2,3$ etc.

1950: 1.@Calafat-Vidin 2kms; 1951: 2.Piatra Neamt-Bicaz 26kms; 3.Dorobantu-Lumina-Capul Midia 34kms; 4. Palas-Lumina 19kms; 1954: 5.Giurgiu-Pod.

Dunăre 5kms; 1957: 6.=Marghita-Voivozi 15kms[]; 1962: 7. Strehaia-Motru 31kms; 1963: 8.Deva-Stoeneşti 14kms; 9.Brad-Dealul Fetii 7kms; 1964: 10.SuceavaPăltinoasa 42kms; 11. Târgu Jiu-Rovinari 15kms; 1966: 12.Barboși-Smârdan 8kms; 1967: 13.Rovinari-Turceni-Filiaşi 62kms; 1968: 14.*Gura Văii-Orșova 23kms; 1971: 15.=Amaradia-Bârseşti 10kms[]; 1977: 16.=Câmpulung-Argeşel 14kms; 1978: 17.Turceni-Dragoteşti 28kms; 1979 18.+Semănătoarea-Eroilor-Tîmpuri Noi 9kms; 1981: 19.* Cozia-Lotru 8kms; 20.+Tîmpuri Noi-Dristor-Republica 10kms; 1983: 21.Târgu Cărbunești-Albeni 9kms; 22 +Eroilor-Industriilor 7kms; 1984: 23. \#Alba Iulia-Zlatna 42kms; 24.+Semănătoarea-Crângaşi 1km; 1985: 25.=\#Voslobeni-Chileni 15kms; 1986: 26.Băbeni-Alunu 44kms; 27. Dorneşti-Siret 16kms; 28.+LupeniBărbăteni 5kms[]; 29. +IMGB-Piața Uniri 10kms; 1987: 30.Dealul Fetii-Stoeneşti 15kms; 31.Paşcani-Târgu Neamt 31kms; 32.Albeni-Calnic 5kms[]; 33.\#Satu Mare-Bixad 51kms; 34.+Crangasi-Gara de Nord 2kms; 35.+Piata Unirii-Pipera 9kms; 1989: 36.Calnic-Seciuri 5kms[]; 37.+Gara de Nord-Dristor 8kms; By 1990: 38.=Jihlava-Dărăști-Ilfov 8kms; 1991: 39.Dângeni-Săveni 16kms; 40+Republica-Antilopa 1km; 2000: 41.+Gara de Nord-I Mai 4kms<> @ train ferry; \# narrow gauge conversion; + Bucharest metro; = freight only; ${ }^{*}$ diversion; [] estimate; <> extension to Laromet expected NEW/EXTENDED FORESTRY SYSTEMS Shown by Roman numbers I, II, III etc.

I Ocna Şugatag; |I Vişeu de Sus; III Teregova; IV; Tismana [a] V Vâlcea [b] VI Câmpu Cetății; VII Întorsura Buzăului [c] VIII Vrancea; IX Oneşti-Râsca; X Roznov [d]; $X_{1}$ Bistrița and Pipirig [d]; XII Fălticeni [e]; XIII Moldovița

[a] partly replacing the Apa Neagră-Turnu Severin narrow gauge railway; [b] Bistrița, Lotru and other systems: see case study; [c] developed from the CFR narrow gauge line transferred to forestry ownership in 1951; [d] built by the Soviet-Romanian joint timber company Sovromlemn; [e] incorporating the isolated Găineşti system

OUTSDTANDING PROJECTS shown by letters $a, b$, c etc.

a.Bixad-Sarasău (i); b.Gilgău-Târgu Lăpuş-Baia Sprie (iii); c.Stana-Zalău (iii); d.Vaşcău-Vârfurile (i/ii); e.Turda-Abrud (ii); f.\#Abrud-Zlatna (ii); g.Sighişoara-Târgu Mureş (ii); h.Odorhei-Ciceu (ii); i.*Bouțari-Sarmizegetusa (ii); j.Răcăjdia-Moldova Nouă (ii); k.Băile Herculane-Balota (ii); I.Stehaia-Ostrovu Mare (Iron Gates II) (ii); m.Alunu-Seciuri (ii); n.Popeşti-Horezu (ii); o.*Lotru-Avrig (ii); p.Leu-Bechet (ii); q.Portăreşti-Bechet-Corabia (ii); r.Vâlcele-Râmnicu Vâlcea (ii); s.ZărneştiCâmpulung (ii); t.Întorsura Buzăului-Nehoiaşu (i/ii); u.Brăila-Tulcea-Sulina (ii); v.Brețcu-Oneşti (i); w. Bacău-Bârlad (i); x.laşi-Huşi-Galați (i); y.Piatra Neamț-Târgu Neamt-Fălticeni-Suceava (i); z..Toplița-Târgu Neamţ (i/ii); aa. Hârlau-Botoşani (i); bb. Săveni-Darabani (i) cc.+l Mai-Laromet (iii); dd.+Grigorescu-Linia de Centura (iii); ee.+Universitatea-Ghencea (iii); ff.+Gara de Nord-Otopeni (iii)

Sources (i) Groza and Muntele (1998); (ii)lordanescu and Georgescu (1986); (iii) Metrorex and others.

- Groşi, Cerna, Copăceni and Berbeşti (total length $3.43 \mathrm{kms}$ ) - were built during 1985 7 for the Alunu line, with three more - Dobrana, Roşia and Seciuri (2.09kms) - during 1987-91 to reach Seciuri. The gap between the two lines (some $8 \mathrm{kms}$ ) was not completed although it was the original intention to make this a through route between Târgu
Jiu and Râmnicu Vâlcea and - with the Vâlcele-Râmnicu Vâlcea route (referred to below) - to shorten the distance between Bucharest and Târgu Jiu to $288 \mathrm{kms}$ (instead of 359 via Craiova) with $339 \mathrm{kms}$ instead of 410 for Petroşani.

The Brad-Deva line was started in 1939 as part of a strategic link between Oradea and Craiova and it retained its importance after the loss of northern Transylvania to Hungary in 1940. Construction advanced across the Mureş at Mintia where a bridge of $301 \mathrm{~m}$ was required, but the viaduct needed at Stoeneşti was not built and the line was eventually opened for the transport of limestone from Crăciuneşti in 1963. At the 
Brad end, Luncoiu viduct (217m) was built so the railway could access the Dealul Fetii mine, while the Hagău and Valea Arinilor viaducts were left incomplete. These outstanding works were ready in 1987 , along with tunnelling at Vălişoara/Ormindea (0.29kms during 1979-82, on top of the two other others $-0.57 \mathrm{kms}$ - already built). But apart from completing 'unfinished business' it is difficult to see what this project achieved since traffic was always light and since 1989 even the modest passenger service (which provided a token 'accelerat' service through Brad to Arad) has disappeared. It is possible that a link with Oradea (via Vârfuri-Vaşcău) was intended to follow on and that the aberration of a 'road to rail' policy was also driving the project. In this context reference should be made to the Curtea de Argeş-Râmnicu Vâlcea line that was first considered in 1890 os and further endorsed by a series of inter-war railway development plans by R.Băiulescu,

A. Cottescu, N. Petculescu and M. Tudoran in which this project vied for priority with the Ilva Mică-Vatra Dornei line of 1938 and the Bumbessti-Livezeni line of 1948. It was seen as the best solution to the bottleneck at Predeal since the summit level would be much lower and the distance from Bucharest to most parts of Transylvania and the northwest would be reduced. On the other hand the costs would exceed incremental improvements to the Predeal line through dieselisation, widening and electrification. Studies were carried out in 1931-2, 1942, 1948-9 and 1957 before a new study in 1975 favoured the route from Vâlcele $(22 \mathrm{kms}$ northwest of Piteşti) to $\mathrm{Bu}$ joreni offering a shorter distance from Piteşti to Râmnicu Vâlcea compared with Curtea de Argeș (62kms compared with $73 \mathrm{kms}$ ) but with $40 \mathrm{kms}$ of new construction instead of $35 \mathrm{kms}$. The chosen route required two tunnels $(4.20 \mathrm{kms}$ built during 1987-90) and 10 viaducts as well as the Argeş and Olt bridges $(3.25 \mathrm{kms})$. Evidently the Predeal route was now approaching capacity even with electrification and double track so that new capacity was needed. The line was nearly finished when the revolution occurred and a train service was actually included in the 1989-90 timetable. But the line was not ready and work was instantly terminated. However after years of neglect, the line has been found a place in the new order as a potential freight carrier allowing dedication of the Predeal to highspeed passenger running. But nothing has yet been done to tackle more than a decade of decay and bring the project through to completion.

A NEW RAILWAY AGE? During the 1980 s an attempt was made to switch traffic from the roads to the electrified railways, supported by lignite-burning power stations and the early prospect of nuclear ca- pacity as well. Along with the repayment of foreign debts, this was part of big effort in the later Ceauşescu years to boost self-sufficiency with reduced dependence on foreign capital and avoid interference by global institutions in economic management. The railways were now carrying far fewer passengers than the buses: $91 \%$ of the total for buses in 1970 but $45 \%$ in 1975 and $33 \%$ in 1980. But there was a sharp increase to $55 \%$ in 1985 , a level maintained until 1989 . In passenger-kilometre terms the same trend occurred: from 2.26 times the road transport score in 1970 to 1.18 in 1975 and 0.97 in 1980 , before recovering to 1.43 in 1985 and 1.54 in 1989 . For freight the recovery was even more striking. In terms of simple tonnage the o.8o figure for $1989 \mathrm{com}$ pares with a low of 0.55 in 1975 while the tonne-kilometre figure of 13.96 times the score for road haulage is more than double the 6.42 score for 1970 . On the negative side however, buses were hit badly by fuel shortages and there were many cancellations, while enterprises and institutes lost their car pools. But on the positive side there was an expansion of the rail network by $364 \mathrm{kms}(3.1 \%)$ between 1970 and 1990 , compared with $159 \mathrm{kms}$ kilometres (1.0\%) between 1950 and 1970.

THE BUCHAREST METRO was first considered 1930 and again 1952 when a Direcția Generală a Metroului was established, although it was thought that the subsoil conditions would require an excessive amount of metal to support the tunnels. But decision to go ahead in 1972 was based on the use of reinforced concrete which had revolutionised building since the 1950 and construction started in 1974 by Întreprinderea Metroul Bucureşti. The growth of a 'necklace' of new estates - like Drumul Taberei and Militari in the west and Pantelimon and Titan in the east - created a need for much greater capacity for cross-city routes and the start coincided with an opportunity to exploit the Dâmbovița alignment since the rehabilitation of the canalised river was linked with a 'cut-and-cover' tunnel on a parallel line that eventually (with some sections of boring) became part of a winding path from Republica in the east to Industriilor in the west (1983); complemented by the northsouth axis from Pipera to IMGB in 1987. Indeed it is not inconceivable that substantial demolition work by the railway engineering company CCCF contributed to Ceauşescu's appetite for massive remodelling of central Bucharest in the 1980s. It was intended that a circle line - 'magistrala inelară - would be completed from Gara de Nord to connect with the major suburban housing developments and generate interchanges with the two axial line at Piața Victoriei, Dristor, Piața Sudului and Armata Poporulu, but only the Crângaşi-
Gara de Nord-Piața Victoriei-Dristor section was completed (Figure 1 inset). Several new arms were also planned in the communist era: Aurel Vlaicu-Băneasa-Otopeni; Nicolae Grigorescu-Linia de Centura, Universitatea-Eroilor-Drumul Taberei and Gara de Nord-București Noi, but with high speed tramways as a cheaper alternative it seemed likely that only the first part of the Bucureşti Noi line would be built (to Laromet) along with the Grogorescu-Centura line. The 'centura' had an influence on the planning through the access provided through the freight line into Militari (with which the Industriilor line connects), just as the other end of the east-west axial line (at Republica) there was a connection with CFR Titan (on an old suburban line through the northeastern part of the city broken up into separate fragments to eliminate level crossings on busy urban highways). Reference should be made to a number of new industrial lines on the inside of the 'centura' e.g. in the Cațelu and Popeşti-Leordeni areas; also from Jihlava to Dărăşti-Ilfov on the outside to connect with the Bucharest-Danube Canal, one of projects of the Ceauşescu Era on which work stopped in 1990. Accurate dates are not available for these industrial lines, although the Dărăști-Ilfov branch was finished only very shortly before the 1989 revolution. Of course the 'centura' (or 'inelul mare') became more heavily used with the further industrialisation of Bucharest and the truncation of the Gara de Nord-Progresul route. Surburban stations were built during 1962-72 to serve local industry (e.g. Berceni for IMGB and Popeşti-Leordeni for Danubiana) although travel times to the city centre by trams and buses were slow. Also most of the 'centura' was widened during 1970-4.

RAILWAY SERVICES TO SMALL TOWNS improved first through conversion from narrow- to standard-gauge: Alba Iulia-Zlatna in 1984 and Satu Mare-Bixad in 1987 (although the conversion of the Voslobeni-Chileni mineral line in 1985 had no such significance); while it was intended that the Băbeni-Alunu line would throw off a branch from Popești to Horezu and an extension to the Bistrița quarry. But most progress was made in Moldavia there were several projects that can only be interpreted as a programme to extend rail services to more urban centres and improve access to raw materials. A short line of $16 \mathrm{kms}$ opened in 1986 to connect the small town of Siret with the main line at Dornești. This was followed by the $31 \mathrm{~km}$ branch from Paşcani to Târgu Neamț in 1987: a line proposed as early as 1891 and started on three previous occasions: 1900, 1914 and 1962 (the latter following a new study started in 1961). Work recommenced in 1981 and was partly justified by the need to move ballast 
from Timissești to the heavy equipment works (CUG) at Iaşi and Holboca power station. The main requirement was the o.84km Cristeşti tunnel built during 19846. Previous studies had suggested an extension of the line beyond Târgu Neamț to Toplița in Transylvania - once seen as a pioneering electrified route linked with hydropower from the Bistrița river - but this was effectively ruled out once the Ilva Mică-Vatra Dornei line (1938) had provided a strategic link between Transylvania and northern Moldavia. A further project was the outstanding goal of a direct line from Iaşi to Botoşani via Hârlau and Vădeni - 105kms instead of 191kms via Dorohoi - tackled by tunnelling north of Hârlau at the terminus of the branch from Podul Iloaei (preferred over the Târgu Frumos variant) that arose out the failure to implement this project back in 1911. The Hârlau branch was repaired in 1946 after serious war damage two years previously, but the extension was not started until 1987 whereupon $16 \mathrm{kms}$ of the $40 \mathrm{~km}$ gap were completed by 1990 including Flămânzi station (also a tunnel of $0.90 \mathrm{kms}$ was virtually finished during1990-4). The railway infrastructure company still has some expectation of completion with 2009 as the target. Another unfinished project of this period was a branch from Dângeni (on the IaşiDorohoi line of 1896) running parallel to the Prut. Such a line was started in 1917 as a narrow gauge link with Lipcani in northern Bessarabia but work stopped with the outbreak of the Russian revolution and only resumed in 1987 in order to reach the sand deposit at Miocani, via Săveni, Darabani and Rădauți Prut, in order to supply the Dorohoi glass works. The line was then restricted to a short branch to the town of Săveni in 1990 and opened the following year, but it was subsequently blocked by a landslide at Vlăsineşti viaduct. No funding has been found to overcome this problem although the CFR plan for a reopening during 2007-9.

Some of this work seems to have been decided quite suddenly because a geographical study of Moldavian railways (Nimigeanu 1981) claimed that projects such as Botoşani-Hârlau and DângeniDarabani had been abandoned. Perhaps - in the context of autonomy allowed to large industrial organisations - the regional railway construction company in Iaşi was able to use its political influence to work on these schemes at a time when electrification and widening had largely run its course and there was a political interest in extending railways as and when resources allowed (albeit without any formal nationwide programme). Apart from the Danube towns of Isaccea, Măcin, Moldova Nouă and Sulina, there were ten towns more than $10 \mathrm{kms}$ from a railway: Baia de
Aramă, Borsec, Horezu, Însuraței, Novaci, Scornicești, Slănic Moldova, Târgu Lăpuş, Vlahița and Vânju Mare. Another 11 were more than five kilometres from a passenger-carrying railway: Bălan, Bolintin Vale, Cavnic, Govora, Hârşova, Mihăileşti, Nucet, Olănești, Solca, Țicleni and Victoria. An economic survey of Oltenia referred not only to small towns like Vânju Mare as possible candidates for rail access, but also rural centres (potential towns in the context of Ceauşescu's rural 'sistematizare' programme) like Bălceşti, Bechet, Cetate, Cujmir, Melinești and Plenița (Barbacioru 1983, p.136). And a study of the forestry potential of the Lăpuş basin in Maramureş recommended a rail link from Târgu Lăpuş to the main line from Baia Mare to Cluj-Napoca at Gilgău (Iacob 1987). Meanwhile, a railway to Moldova Nouă had already been discussed first in the context of a Hungarian project just before 1914 for the Nera valley to connect Iablanița near Orşova with the TimişoaraBaziaş line. After World War Two the mining and metallurgical company operating in the Anina-Reşița area (UDR) envisaged a dam on the Nera at Sasca and a branch from Răcăjdia near Oravița to Moldova Nouă was studied with summit tunnel of $3 . \mathrm{kmm}$ on the route to Pojejena. However this was abandoned in preference to rehabilitation of the Turnu Severin-Orşova line (Iordănescu \& Georgescu pp.I.609-10) presumably before the agenda moved further ahead with realignment for the hydropower scheme. The Moldova Nouă link was one of a number of projects on the CFR's 'wish list' (Ibid, p.II.567) which also included some long-standing Carpathian ambitions, rural lines in the Bechet area of Oltenia to serve an important irrigated agricultural area, a link from Brăila to Iasaccea, Tulcea and possibly Sulina, an Apuseni project to widen the Turda-Abrud narrow-gauge and extend it to Zlatna, a further diversion for hydropower development in the Olt valley and a substitute for the rack system to allow the reopening of the Bouțari-Sarmizegetusa line. Some of these projects continued to appear in development plans in the early 1990 o (even some new projects such as a branch to the small town of Bolintin Vale near Bucharest). The Răcăjdia-Moldova Nouă line was again discussed as a way of improving export outlets for the heavy in dustries of Reşița (Figure 1). All this points to a reasonably coherent 'pro-railway' lobby in the party in the 1980 os, although it was not formalised in any documents for public consumption and did not surface in any of Ceauşescu's speeches. Although development became focused on the European transport corridors in the later 1990s, Gro$\mathrm{za}$ and Muntele (1998) were keen to recommend a whole clutch of railway projects for improved network connectivity, while the journal 'Revista CFR' reminded its readers in 2002 that the Hârlau-Botoşani and Vâlcele-Râmnicu Vâlcea projects were outstanding and restated the advantages of completion (from the current $75 \%$ level) over the alternative of delay and further deterioration.

Evidence against this conclusion would come from some 70 cases of passenger service withdrawals indicated by timetables However these all relate to short sections of track - frontier crossings in 26 cases; another 26 for short standard gauge branches (retaining a freight service in many cases) while seven relate to network adjustment in cities, five involve track realignments and six are narrow gauge branches. The vast majority occurred before 1970 when road transport by bus and lorry was seen as the optimum transport solution for local feeder systems serving the main line railways. Discussion of the role of narrow gauge railways in agricultural areas in the early 1950 (Lupse 1955) - complementing the forest railways referred to later in this paper - was diverted by the improved oil supply in the late 1950s (with new oilfields in production and reparations to the Soviet Union terminated) and the expanding vehicle industry. Of the 13 closures that came later, the only casualties of the 1980s were due to technical obsolescence - the central (rack) section on the Caransebes Subcetate line - and the historic suburban electrified services from Arad to Pâncota and Radna.

\section{Development of the existing network}

Limited achievement over new railways should not imply that the railways remained static. The existing infrastructure had to be developed to meet to needs of the country's core economic areas, reflected by a regional planning and administrative system of 16 regions (quickly reduced from the original 28) and then extended to 40 counties under the reform of 1968 . There was initially a second tier comprising 194 districts (including some large urban areas where cities enjoyed a wider coordinating role: Braşov (renamed Stalin in the 1950s), Bucharest, Cluj-Napoca, Constanța, Petroşani, Reşiţa and Suceava) reduced to 150 by 1968 . However the focus was clearly concentrated on the regional centres and small-scale 'local' industry was not a major priority, for 35 of the 194 district centres failed to achieve urban status: their industrial development was restricted to food processing, mining or wood-cutting where suitable resources were available. Therefore, except in a few cases where major new demands arose (though lignite quarrying for example), industrial development did not require any extension of the railway network. An atlas showing communist 
achievements in industry in the early years (Paptănase \& Vornicescu 1964) shows 143 'large' units in the regional centres (18.3\%) and a further 86 in the 12 centres that were demoted during the 1950 o (11.0\%). This still indicates a substantial level of decentralisation to district centres, although no allowance is made for the scale of production or level of employment and the industrial establishments of the largest cities (especially Bucharest) are under-represented. Meanwhile, 403 units were established in 86 districts with a town as the administrative centre (51.5\%). Another 107 enterprises $(13.7 \%)$ fell to 43 districts focussed on towns promoted to urban status between 1948 and 1968 (including status regained at Baia de Aramă, Darabani, Huedin and Săveni, initially demoted) leaving only 40 enterprises $(5.1 \%)$ in 35 districts that remained rural throughout. This meant 4.0 projects per district across the country but 5.6 in districts with urban centres, 2.4 in districts where promotion occurred and 1.1 where it did not.

At the same time, virtually all the enterprises were in districts where the centre had a rail service. Only 24 centres lacked this facility (and this figure fell to 11 as a result of reorganisation to reduce the total number of districts to 150). There were only 32 enterprises in these centres: 13 (out of 634) in existing towns (Hârşova, Măcin, Târgu Neamț and Siret), 15 (out of 107) in places promoted to urban status (Baia de Aramă, Darabani, Horezu, Moldova Nouă, Novaci, Săveni, Târgu Lăpuş and Vânju Mare) and four (out of 40) in rural districts. The significance of railways was all the greater when it is noted that 10 of the 32 enterprises in non-rail centres comprised towns on the Danube (Hârşova, Măcin and Moldova Nouă, enjoying navigation facilities) with a further four in districts with centres very close to a railhead like Drăgănești-Olt and Săveni and Vidra. These figures suggest that rail access was a major consideration in location policy; yet despite the regime's initial commitment to decentralisation and the growth of local industry, the central planning exercise did not have the financial and administrative resources to cope with too many locations. Strong industrial establishments in all districts, with new railways for those areas lacking such communications, was clearly not a feasible option. Of course academic studies dealing with the potential of individual rural districts might recommend a railway extensions as a solution to local transport problems (Velcea \& Cucu 1956). But this was not a feasible option and in many rural centres lacking rail access enterprises were generally concerned with woodcutting and mining that could not be concentrated in urban centres. In the case of Vidra, the centre of the Vrancea raion in the region of Putna (progressively merged into larger regions based on Bârlad and then Galați), the village lay very close to Burca that was the terminus of the narrowgauge railway from Odobeşti. A road haulage depot was built in the station yard and a railway extension through Vidra to Valea Sării was seen as a logical solution to the transport problem in view of the potential for wood processing. But industrial development (tied up largely with food processing) was abruptly halted when the regional authorities in Bârlad decided to consolidate manufacturing in the regional centre in the interests of greater efficiency. Later reorganisation meant that only two district centres lacked rail (or river) transport and also failed to gain promotion to urban status by 1968: Bălceşti near Craiova and Băneasa (Constanța). Of course, branch-

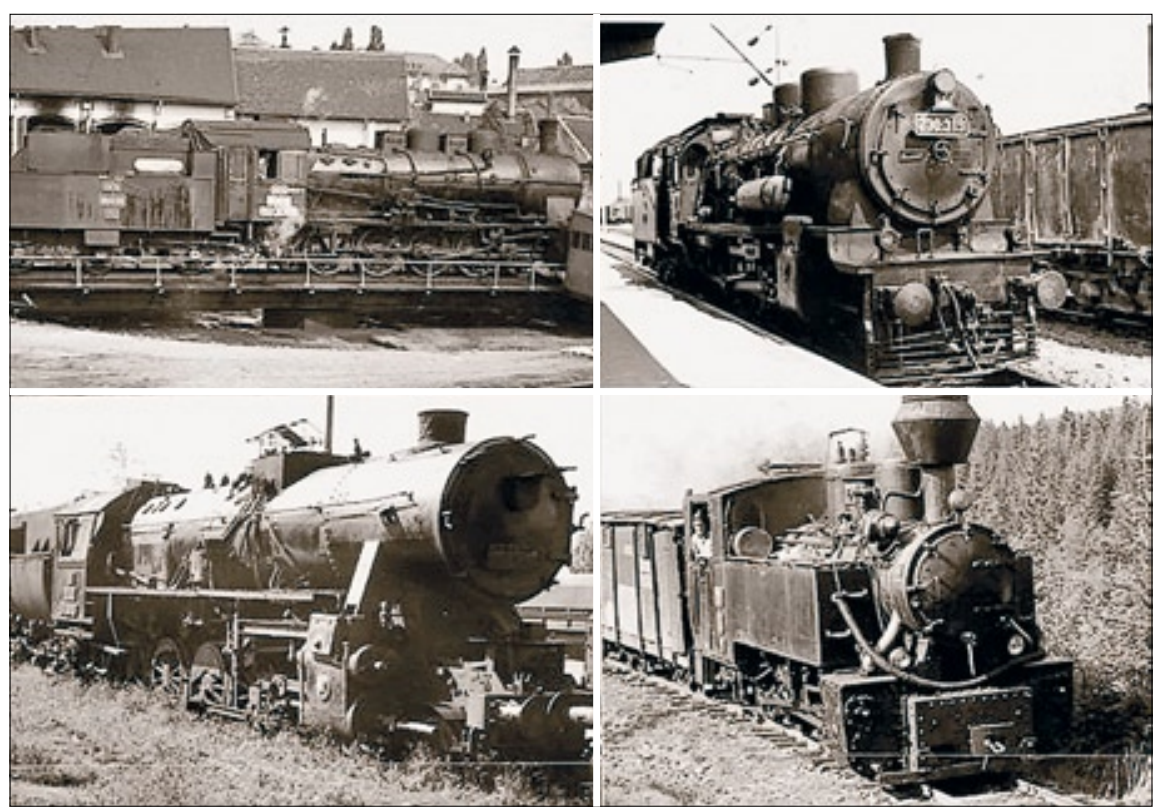

Plate 2 Steam locomotive types featuring the two key inherited standard classes: 0-10-o Class 50 on the turntable at Drobeta-Turnu Severin (top left) and 4-6-o Class 230 at Deva (top right). Also the 2-10-o heavy freight locomotive developed from the German 'Kriegslok' in store at Oravița (bottom left) and a 1950s Reşita-built 0-8-o narrow gauge forest railway locomotive on the Comandău system

es required in connection with mineral resources (coal at Uricani; lignite at Motru and Rovinari) and hydro-electric schemes (Bicaz) were hailed as successes for backward area policy (Moldovan 1964) but such investments were only made in the context of compelling natural resources and industrial potentials.

Thus there was a rapid growth of traffic on the existing rail system, particularly evident for coal and light manufactures, while coke. wood, firewood, building materials, cereals and food lost ground relatively; leaving oil, engineering products, quarry products and sugar beet down slightly overall. These traffics affected the main lines in roughly equal measure. But the movement of wood was pronounced between Suceava and Bucharest; while cereals were particularly prominent on the line from Banat to Craiova and thence to
Bucharest and the ports of Constanta and Brăila; complemented by southward-moving flows from Moldavia (Bacău and Bârlad). Oil flowed from Constanţa to Ploieşti while refined products were distributed to Bucharest and the provinces; while quarry products were prominent on lines to Bucharest from Constanța, Mărăşești and Piteşti. Iron ore trains originated at Constanța and Galați supplying Reşița (via Craiova) and Hunedoara (via Ploiești and Braşov) respectively. Coal flows were highest on the axis from Deva to Petroşani, Târgu Jiu and Craiova: both hard coal from Petroşani and lignite from the area southwest of Târgu Jiu moving to power stations at Craiova, Deva, and Turceni.

TRACTION POLICY. Initially there was an expansion of steam power, albe it with the abandonment of Romanian 

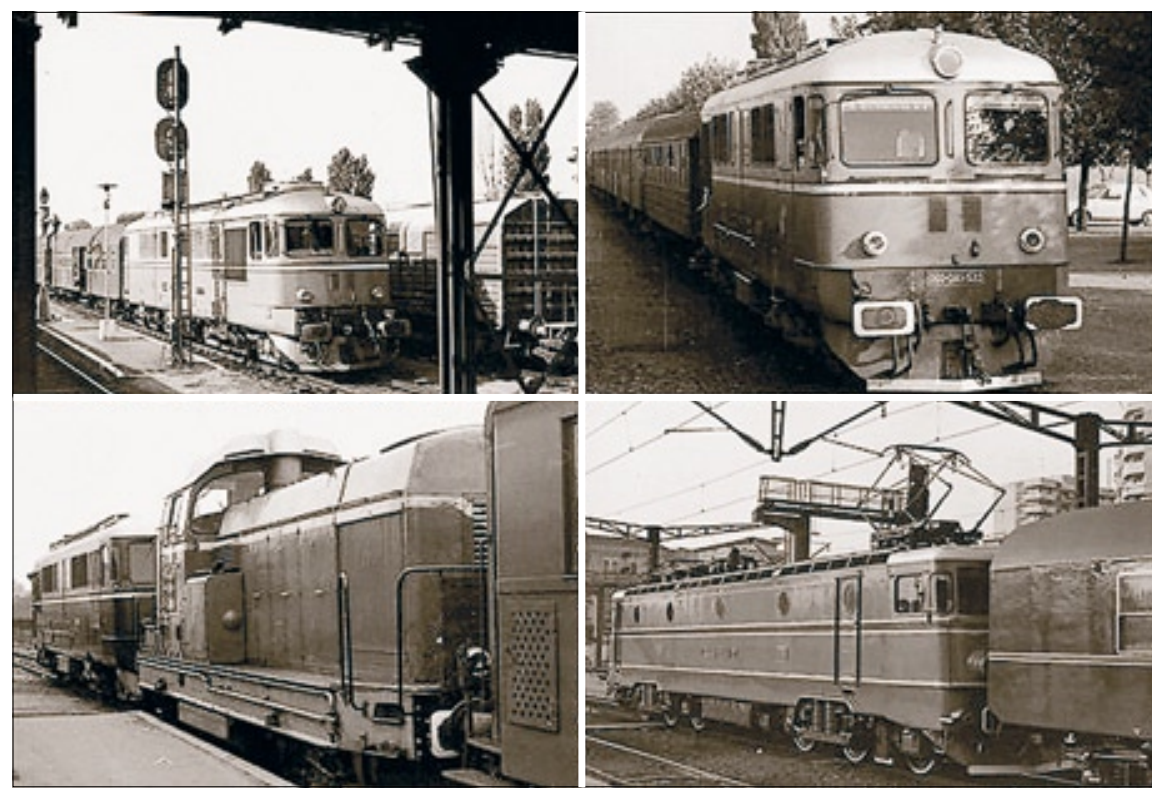

Plate 3 Diesel and electric locomotives: the 2,10ohp Sulzer diesel-electric at Slatina (top left) and Alexandria (top right). Another 2,10ohp diesel-electric pilots a 1,250hp diesel-hydraulic on a Craiova-Calafat stopping train (bottom left); and a 7,10ohp electric locomotive enters Bucharest's Gara de Nord (bottom right)

Raba engines from 1981 (Plate 3), dieselisation began when CFR approached a Sulzer-led consortium over a new locomotive for the Predeal line that was delivered in 1938 and - along with widening to double track - helped to ease the bottleneck. And when interest in dieselisation revived in the context of a much-improved oil supply, traditional links with Switzerland produced the first six locomotives from SulzerBrown Boveri (1959) in what proved to be a large and successful class of some 1,500 2,10ohp diesel-electrics built under licence by Electroputere (Craiova) during 1960-91 and used countrywide for mixed traffic though they were limited to $100 \mathrm{~km} / \mathrm{h}$, consumed fuel heavily and did not train-heat-
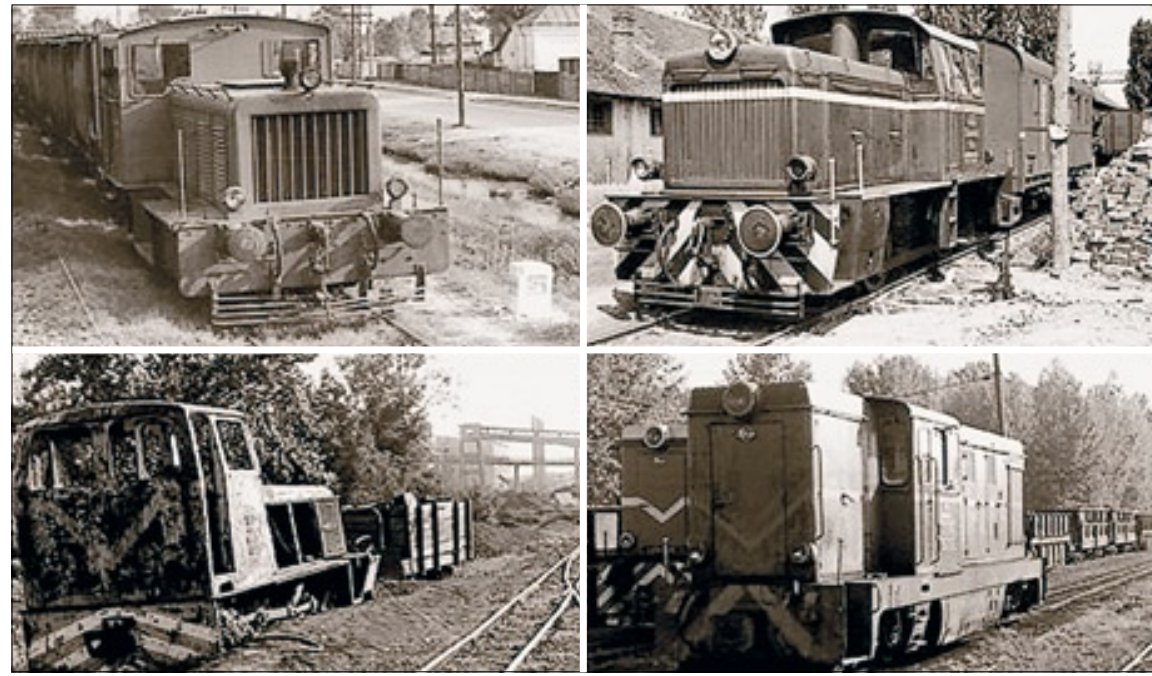

Plate $4 \mathrm{~A}$ set of low-powered diesel locomotives. One of the earliest diesel-mechanical shunting locomotives - Class 20,000 120hp, first built by Malaxa (Bucharest) in 1934 - at Alexandria (top left); a more modern type - 250hp diesel-hydraulic built by 23 August (successor to Malaxa) in the 1970 s and 1980s - at Deva (top right); another later model - a diesel mechanical for the narrow gauge built by 23 August in the mid-1960s - abandoned at Voivozi (bottom left); and a brace of 23 August 350-450hp diesel hydraulics (Class 87) at Voivozi: built for the narrow-gauge by 23 August during 1966-89 (bottom right) through the 1980s, although the bogies did not ride well and - due to inadequate maintenance and poor quality lubricants - the class had limited life and disappeared in the early 1990 .

Electrification had already been muchdiscussed for a law was passed to authorise the Bucharest-Braşov electrification in 1929 and the CFR administration set up a 'Direcția Electrificării' in 1942 under D.Leonida, while the widening at Predeal anticipated electrification when two new tunnels were bored at Timişul de Sus in 1946-8 and it seemed that the new priority for a national electricity grid would have a positive effect on railway conversion. This was mooted in the case of CâmpinaBraşov in 1952, but abandoned under the 'new course' in favour of dieselisation. By 1963 the Romanians were again considering electrification and technical visit was made to the UK to study the $25 \mathrm{Kv}$ system. Work started in 1965 and by 1969 the entire line was Bucharest to Braşov was electrified (coinciding with full utilisation of the greater capacity provided by dieselisation). The search for a standard locomotive in 1963 favoured ASEA of Sweden whose 7,10ohp design was again built under licence by Electroputere during 1967-94 (and yielded some exports Bulgaria, China and Yugoslavia: exchanged in the latter case for a smaller 4,ooohp variant built by Rade Končar in Zagreb) (Plate 4). As a result of this major building effort between 1965 and 1970 - involving c.70o locomotives - about $90 \%$ of all traction was handled by diesel and electric locomotives in the early 1970 s compared with little more than one percent in 1960. The new locomotives also incorporated radio control as a part of a modernised system of control and signalling. The 'electro-dynamic' system replaced the electro-mechanical system and 725 switches were so controlled by 1960 (the year after the first electro-dynamic signalling and switching installation of Romanian manufacture was installed at Bod near Braşov). Centralised control at stations was adopted from 1962 with scope for direct communication with train crews.

Strangely, there was little further interest in railcars for light passenger workings beyond the retention of the existing fleets with new Maybach engines. The 'Sageata Albastră' (Blue Arrow) was built in 1959 to operate a prestigious holiday service between Vienna and the Black Sea. But the two trains - each of six units of which two were powered by Maybach engines - were restricted to limited operations with foreign tourists on the Bucharest-Constanța line. New prototype railcars were built for branch line use (especially in the $\mathrm{Bu}$ charest area) in 1984 and 1989 by $23 \mathrm{Au}$ gust with Raba engines but without series 
production. And sets of electrical multiple units were built by Electroputere in 1974-5 (using Czech equipment) for service in the Bucharest, Craiova and Cluj-Napoca areas. But their lifespan was limited by a lack of proper maintenance installations and all were withdrawn before 1989 . Meanwhile, the country built its own rolling stock with a margin for export: passenger coaches at Arad and wagons at Caracal, Drobeta-Turnu Severin and Paşcani. There was also provision of new rolling stock with four wheel bogies, all built within the country: 1,100 coaches and 4,500 wagons between 1965 and 1970 alone. For passenger trains $42 t$ coaches were introduced for both first and second class - 54 and 80 seats respectively (also sleeping cars to accommodate 22 persons and two-storey coaches with 120 seats) (Plate 5). There was also some new narrow-gauge stock (Plate 6). For freight the standard open and covered wagons, platform wagons and tank wagons ranged from 23-25t with capacities of 56-61t.

TRACK IMPROVEMENTS: WIDENING. Much investment was needed in new track. Rail standardisation (from 1950) involved heavier rails $(45-49 \mathrm{~kg} / \mathrm{m})$ to accept axle weights of 20.5t compared with 16-18 at the beginning of the period. Welded rails were laid experimentally on sections of the Bucharest-Urziceni line in 1957 and widely adopted thereafter, allowing speeds of up to $16 \mathrm{okm} / \mathrm{h}$. In many places special engineering works were needed. A new viaduct of $181 \mathrm{~m}$ was erected at Valea Porcului in 1955 on the Deda-Sărățel line, built during Hungary's war-time occupation of northern Transylvania to simplify access to the Harghița and Covasna from the northwest. This new link from Braşov and Miercurea Ciuc - leading directly the key junction of Dej - was then greatly valued by Romania as a more direct route from Bucharest to Baia Mare ( $458 \mathrm{kms}$ compared with $499 \mathrm{kms}$ via Cluj) although it was never advocated as a desirable improvement by Romanian engineers. Therefore steps were taken to improve on a temporary work (involving a sharp curve of $150 \mathrm{~m}$ ) undertaken by the Hungarians at a site where it was difficult to lay foundations. Also, the key bridge at Barboşi near Galați that was damaged in the war was repaired definitively in 1956 after the temporary solution of 1945, with a second track on a new alignment in 1971. Flood defence called for major works on the Făurei-Tecuci line carried out in 1957-8 after the floods of 1952 on the Bentu-Deduleşti section of the Buzău valley (through dyking and canalisation of the river) to protect the bridge north of Făurei with similar work at the crossing of the Siret at Suraia. Attention was also needed to the Siret at Cosmeşti (between Mărăşeşti and Tecuci) during 1955-65 with further atten-

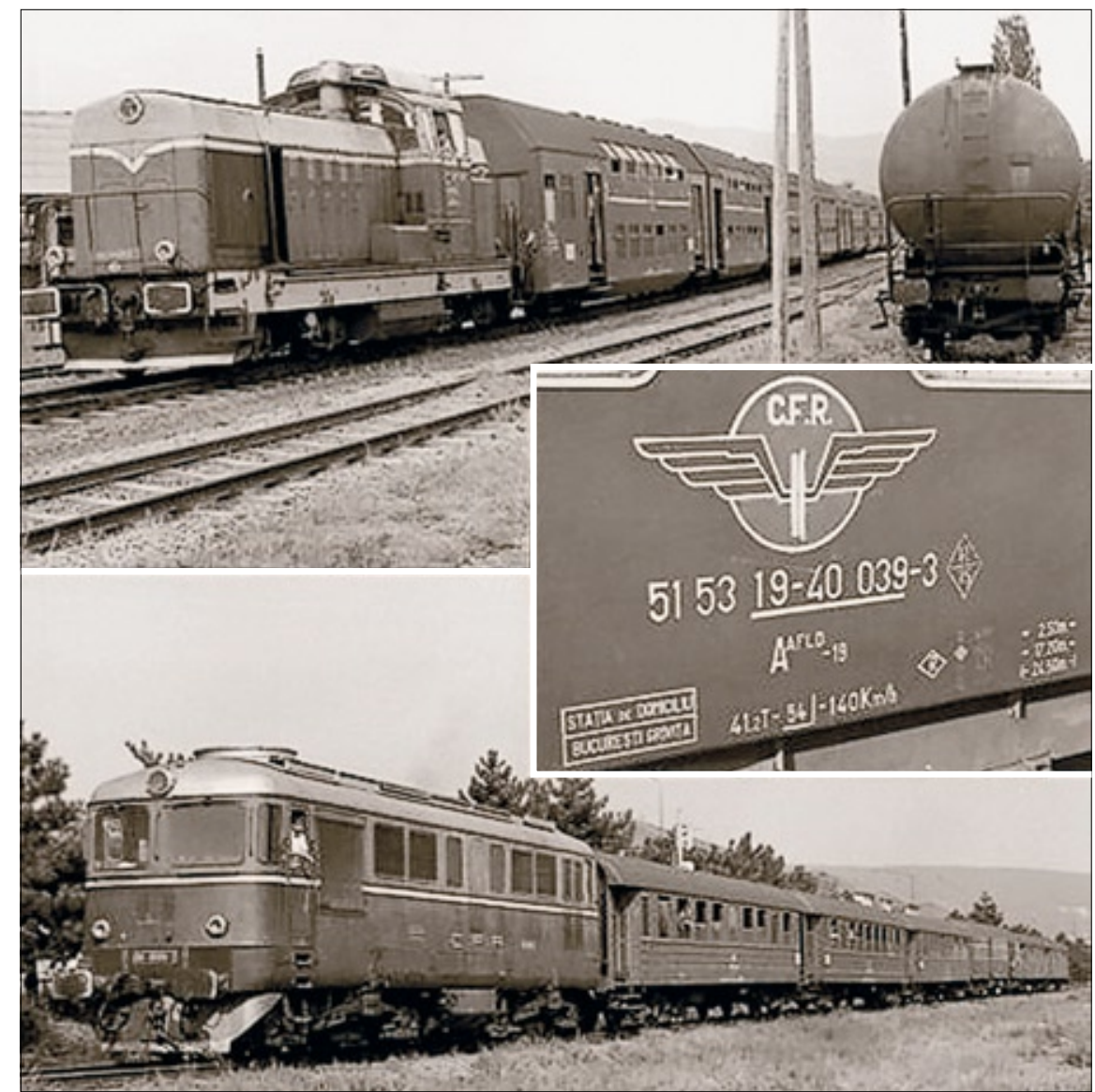

Plate 5 A 1,25ohp diesel-hydraulic locomotive at Pătârlagele on the Buzău-Nehoiaşu branch with one of 120 rakes of double-deck coaches imported from Waggonbau Görlitz during 1965-73 for busy commuter lines (above); a 2,10ohp diesel-electric takes a rake of coaches out of Râmnicu Vâlcea: the first three are early post-war Arad-built coaches - named 'Dimitrov Cars' because the Astra factory was renamed for a time in honour of the Bulgarian communist leader Georgi Dimitrov - formerly for express trains (but later displaced to stopping trains); with the last two new coaches built in Arad from 1964 based on a design from Pafawag Wrocław for use on stopping trains (below); and markings on a 'Type $Y^{\prime}$ ' coach built in the 1960 s for express passenger workings

tion to the river on the Adjud-Bacău section on several occasions between 1949 and 1964. And four kilometres from Paşcani a meander on the Siret had to be cut through

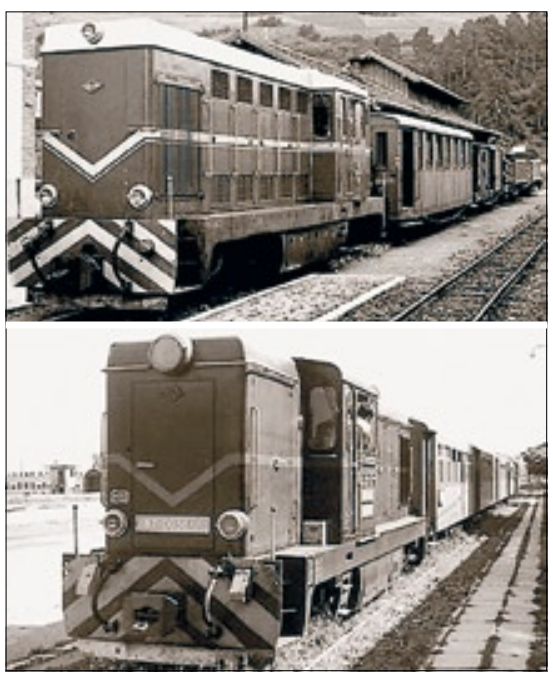

Plate 623 August diesel-hydraulic

locomotives on the narrow gauge: at Câmpeni on the Turda-Abrud line with a mixed train including a passenger coach of 1950 s vintage built by Unio of Satu Mare (above); and another at Sibiu with a rake of more modern coaches built by MEVA (Drobeta-Turnu Severin) in the 1980 s for the Agnita branch in 1964-5 when further enlargement would have threatened the line to Iaşi. Protection was needed on the Ialomița at Teiş and in the Buzău valley above Măgura after flooding in 1975. Steep valley sides needed massive works of stabilisation e.g. in the Jiu valley while the danger of rockfalls led to the building of shelters at Turnu in the Olt valley in 1957 and Lainici in the Jiu valley in 1972-3. Many main line stations were rebuilt - most notably at Baia Mare, Bârlad, Craiova, Mediaş, Piteşti and Tulcea - while at Constanța (1960) and Braşov (1962) new stations were built on a completely different alignment (at Braşov there was a $1.5 \mathrm{~km}$ shift in location from the city centre to the former freight yard where a new east-west alignment was imposed).

The greatest developments on the track related to widening (to provide two tracks on formerly single track lines) and electrification. In 1950 only $0.5 \%$ of standard gauge network was wide compared with $10.7 \%$ in 1970 and $27.0 \%$ in 1989 . The comparable figures for electrification were $0.05 \%$, $4.8 \%$ and $33.5 \%$. In 1945 the network of widened lines was limited mainly to BucharestBraşov (thanks to the major programme in the Prahova valley finished in 1940) and 


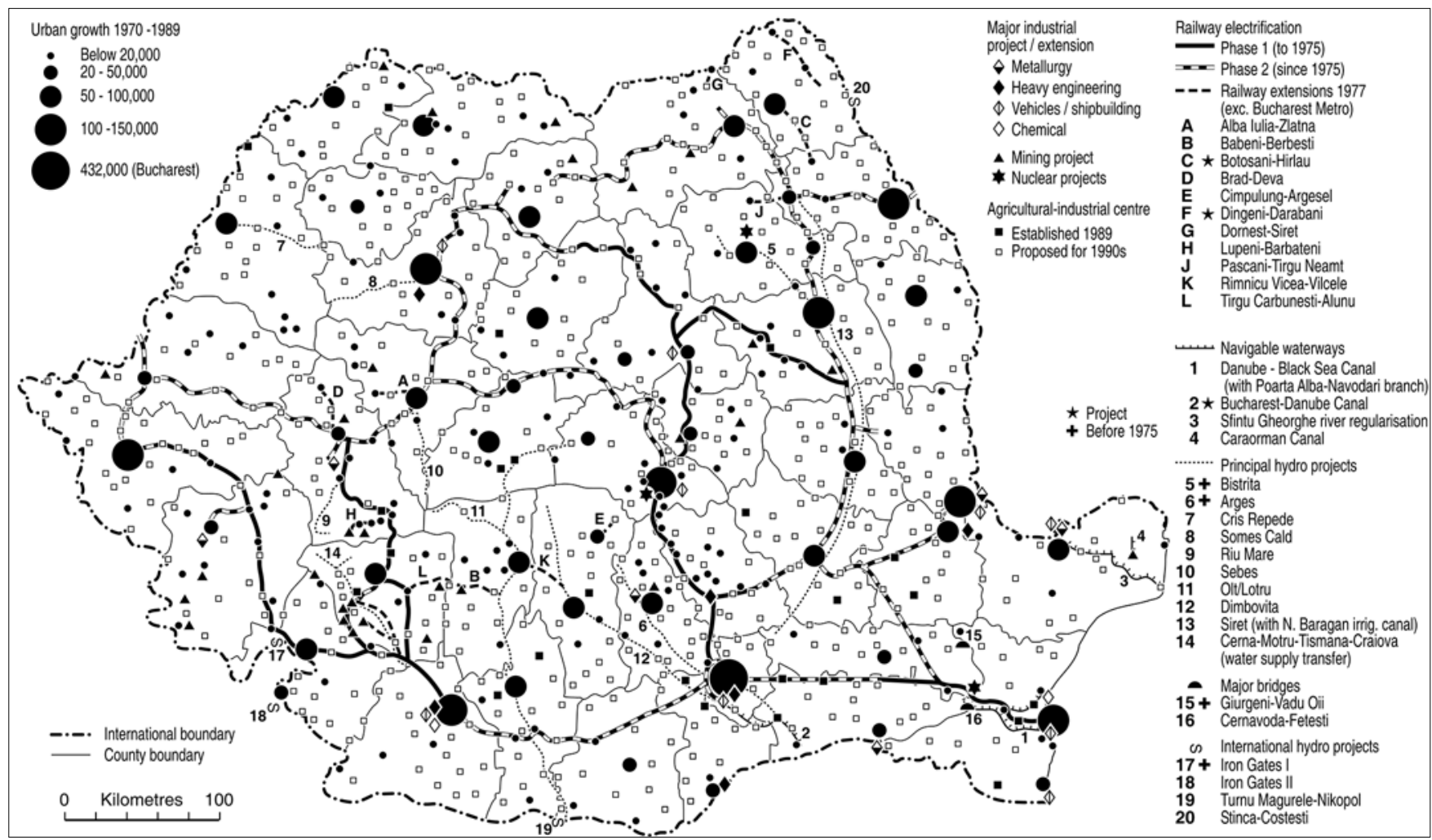

Figure 2 Ceauşescu's construction programme for the 1970 and $1980 \mathrm{~s}$

from Ploieşti to Adjud and Tecuci. There were also sections in the provinces such as Constanța-Cernavodă, Copşa Mică-TeiuşApahida (near Cluj-Napoca) - subsequently dismantled - and Iaşi-Lețcani. Some short sections were widened during the 1950s, but it was after 1965 when the main work began with $1,439 \mathrm{kms}$ widened during 1966-78. The long section from Braşov to Teiuş and thence northwards to Dej and westwards to Hunedoara and Ilia (west of Deva) began with the short Simeria-Hunedoara section in 1953; then Războieni-Apahida and Vințul de Jos-Ilia in 1960 followed by Braşov-Teiuş-Războieni/Vințul de Jos and Apahida-Dej-Beclean during 1970-4. In the Craiova direction the Craiova-Filiaşi section was widened in 1951; followed by Bucharest-Craiova and $\mathrm{Bu}$ charest-Piteşti during 1965-72 and FiliaşiStrehaia in 1975. The Buzău-Făurei-Galați line was widened in two stages: the latter during 1965-71 and the former during 19745, with Făurei-Feteşti dealt with in the interim (1970-2). The Bucharest-Cernavodă line - meeting the existing double track to Constanța - was widened during 1969-71. And in Moldavia doubling was extended from Adjud to Suceava and from Paşcani to Lețcani during 1972-5. Work started on the line from Cluj-Napoca to Oradea line in 1973 and later in the decade - continuing through the 1980s - other sections were dealt with, such as Galați-Tecuci, BârladIaşi, Dej-Jibou, Sibiu-Vințul de Jos (extending the work done between Podul Olt and Sibiu in 1958-9). Widening involved some major engineering work where additional tunnels had to be bored (for example the 770m Fileşti tunnel between Galați and Barboşi during 1964-7). Duplication of seven tunnels (with a total length of $2.46 \mathrm{kms}$ ) was required between Braşov and Oradea during 1973-83 including Stana (between Cluj and Huedin) where the new $234 \mathrm{~m}$ tunnel of $1975-6$ followed the $294 \mathrm{~m}$ single bore of 1945-7 that, in turn, proceeded a temporary 23om realignment in 1945 above the original tunnel damaged in the war. Widening of the Petroşani-Simeria coal-carrying line required eight tunnels (total length of $1.46 \mathrm{kms}$ ) during $1985-90$ and another epic was the new $1.67 \mathrm{~km}$ tunnel bored at Mestecăniş (between Câmpulung Moldovenesc and Vatra Dornei during 1976-9 with a steady gradient of 25.0 per thousand (compared with 20.0 for the old tunnel which had always posed as a serious bottleneck, especially for long-distance traffic after 1938). Some of the widening work was very challenging like the Apoldu de Sus-Sălişte section of the SibiuVințul de Jos line developed during 1977-80. Iordănescu and Georgescu (1986, p.II.566) foresaw the need for much more widening to cover the entire line from Braşov to Baia Mare via Ciceu as well as Ciceu-Adjud; also Constanța-Mangalia, Filiaşi-Târgu Jiu-Petroşani, Ilia-Lugoj and Piteşti-Piatra Olt-Sibiu - and even tripling on short sections like Bucharest-Ploieşti, MărăşeştiTecuci and Vințul de Jos-Apahida. Another likely requirement was widening on the entire line from Bucharest to Craiova and Timişoara and because the section through the Iron Gates could not be developed (due to flooding after the viaducts and support structures has been installed for single track only) an ambitious new route was proposed by tunnelling through the Mehedinți Mountains from Băile Herculane to cross the Bahna river and follow the Topolnița to the top of the spiral at Balota above Drobeta-Turnu Severin. In this way the route would have been shortened and the notoriously difficult bank between Turnu Severin and Balota avoided. But with the reduction in traffic since 1989 these challenges have gone away apart from the Gura Motrului-Turceni-Târgu Jiu line through the Oltenian lignite field (which has a substantial passenger service in addition to coal traffic to Turceni power station) and the Galați-Iaşi line via Bârlad is significant in the context of the Eurocorridors.

ELECTRIFICATION was another mas sive undertaking - part of Ceauşescu's programme of accelerated modernisation summarised in Figure 2 - that was generally phased in later than widening: starting in 1959 with completion at Predeal-Braşov (1965), Predeal-Câmpina (1966) and the entire Bucharest-Braşov line (1969), followed by Craiova-Reşița (1971), Filiaşi to Deva via the Jiu valley (1973), Braşov-Ciceu-Dej (also the Bistrița branch) and the trans-Carpathian Ciceu-Adjud line (1978). These were mostly single-track railways where conversion served to increase capacity without the need for widening (still deemed to be unnecessary). BucharestConstanța was converted by 1978 and the Bucharest-Craiova line in 1979, both in the decade following the completion of widening. And by 1984 conversion had spread from Ploieşti to Suceava and Iaşi, from 
Braşov to Teiuş - and from there to Arad/ Caransebeş and Dej, Bucharest to Piteşti and Buzău-Faurei-Galați/Făurei-Feteşti; also Ilia-Arad with Salva-Suceava completed since 1989. Electrified railway thus increased from just $58 \mathrm{kms}$ in 1950 (relating to a former Hungarian suburban system in the Arad area) and $224 \mathrm{kms}$ in 1970 to $3,680 \mathrm{kms}$ in 1990 with the greatest progress made during the 1970 s when $2,143 \mathrm{kms}$ were converted. Only in a few cases like Filiaşi-Strehaia was single track widened after electrification. Again much engineering was required to reprofile tunnels with the Jiu valley line a particular challenge in this respect, as well as the new Mestecăniş tunnel that had to reprofiled in the 1980 os. In some cases entirely new bores were needed as in the case of the OrşovaCaransebeş line where two new tunnels (total length $1.36 \mathrm{kms}$ ) were made during the 1970s. At Strapița this led to a return to the original alignment of 1878 after the threat of river erosion had caused a diversion to be taken in 1911-3.

\section{Narrow gauge for the CFR and the romanian forests}

The paper has made relatively little mention of industrial lines although there were numerous short spurs giving access to factories and depots (Plate 7). However, in the context of narrow-gauge lines the system operated by CFR - albeit reduced by closures and conversions - was very small in relation to the network of 'industrial' lines for the forests, including many built in the 1950s. Indeed if there was a 'heroic' phase of new railway construction it arguably involved the forestry sector. Nationalisation of forests paved the way for planning on the basis of large units - 'unități forestiere mari' - comprising whole river basins and $80 \%$ of these were accessed by railway, road or funicular (cable) systems, compared with $10 \%$ for canals or animal haulage while another $10 \%$ remained inaccessible. Many new $760 \mathrm{~mm}$ railways were needed: indeed it is estimated that an increase of $336 \mathrm{kms}$ between 1944 and 1950 was followed by a further $1,048 \mathrm{kms}$ during 1951-5 and 321 kms during 1956-8 built by the Ministry of Forests Paper \& Cellulose using local patriotic labour to expand the network of forest railways ('căile ferate forestiere': CFF) to a total of some 6, oookms. Given the pressure to maintain the high level of wartime timber output (partly for reparations to the USSR) in the face of a severe oil shortage and inadequate road transport, there was a short phase of intensive development to open up new sections of the Carpathian forest and allow the most accessible areas some respite. Some entirely new systems were constructed as shown in Figure 1 but it was more usual for existing systems to be extended, most notably in the case of the Sighet system in Maramures that now reached the Runcu and Şugău valleys, while in Neamț new lines at Roznov and Pipirig were complemented by an enlarged Bistrița rafting system that spawned short railways in the Criştişor and Om valleys. Several major new funiculars were built in Vrancea to simplify movements to sawmills (CăldariSecuiu to carry Zăbala valley timber to Nehoiu sawmill and Motnău-Rădurii to link the Râmnicu Sărat valley with Gugești sawmill) while Oituz sawmill had a funicular link with the CFR at Brețcu.

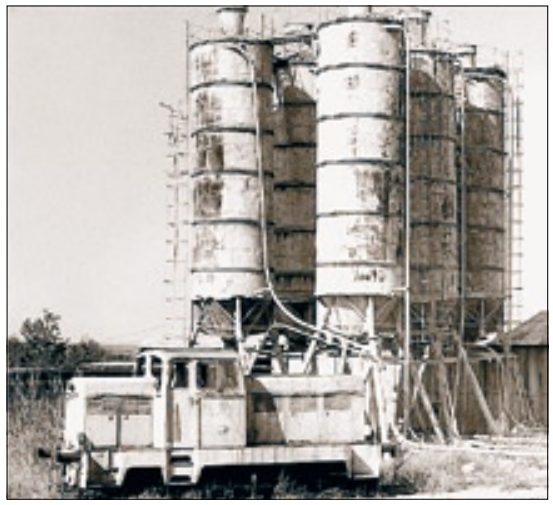

Plate 7 One of the many short industrial branches: giving access to a cement depot at Oravița with another diesel mechanical shunting locomotive type in the foreground: a modernised version of Class 20,000 built by 23 August in the mid-1960s

Forest railways handled $53 \%$ of all timber transport in 1955 compared with $44 \%$ in 1944 and their primacy was not seriously compromised until 1958 when the rise in oil production and the priority for the home market (rather than exports to the Soviet Union) gave a boost to the Romanian vehicle-building industry. Road transport was considered to be much cheaper than rail and special trucks were designed for the timber industry (including a winching system that enabled drivers to load their lorries unaided). A change in direction was spelt out by the Eighth Congress of the RCP in 1958 and major review of forest transport was carried out by the Institut de Studii şi Proiectări în Industria Lemnului in 1960-1 paved the way for a switch to forest roads that made a radical impact in areas like Vrancea that had previously sent timber to factories outside the district by funiculars. Steeper valleys could now be negotiated and most funiculars closed, while the emergence of a network of large centralised wood processing units in urban centres made the existing railways less useful: many closed during the 1960 (especially those costly to maintain, with flood damage accelerating the process in some cases). Significantly however, rising oil prices in the 1970 s prompted a decision to retain those systems that were still in existence: they survived until 1989 and two are still in existence - at Moldovița and Vişeu de Sus - with timber transport and heritage functions. Two others were transferred to industrial users in c.1970: one at Borsec for mineral water (now closed) and other at Bistrița (Vâlcea) that still carries limestone to the Govora chemical factory. In the 1980 os at a time of strong political support for railways some new branches were built at Moldovița and Râsca (the surviving section of the Fălticeni system) and the state logging company at Caransebeş had plans for two new railways at Voislova and Zăvoi.

THE CASE OF VÂlCEA COUNTY. Space does not permit a detailed review but the engineering challenges are no better seen that in the Vâlcea area where railways had to access the forests from the relatively low level of the Olt defile through which a main line railway was built in 1901 (Figure 3). The history of commercial forest exploitation initially focused on the Lotru valley that gave access to resinous timber on the eastern flanks of the Parâng Mountains. Water-powered sawmills in the Lotru valley appeared from the mid-19th century feeding timber to the main highway along the Olt valley. From small beginnings the business was consolidated in 1873 when Carol Novac's sawmill opened in Brezoi, served by a floating system on the Lotru (continuing through rafting on the Olt to sawmills at Slatina, Stoeneşti and Turnu Măgurele) maintained by the partners of the large capitalist company ('Oltul') formed in 1904. Meanwhile, the Olt railway was followed by a road along the Lotru - and the addition of a tourist function to the logging village of Voineasa - while forest railways were pushed up tributary valleys like the Păscoaia/Priboiasa (1922-60), Vasilat (1914-40) and Voineşița in the inter-war years $(15 \mathrm{kms}$ in the case of the Voineşița, worked by locomotives assembled from pieces) (Moga \& Stanciu 2002). There were also short branches in the Malaia area alomg the lower reaches of the Bucureasa, Căprăreasa and Păisul valleys. Finally, the decay of the floating system during the Second World War, along with flood damage and the expectation of hydro-electrical developments, resulted in a forest railway all the way along the main valley from Brezoi to Voineasa after nationalisation (1948-54), with a number of funiculars to open up remote parts of the Lotru catchment. But due to technical difficulties it was not possible to extend the railway along the Latorița valley although a road has now been constructed.

However during the inter-war years a new challenge was posed with regard to the mixed beech and coniferous forests lying south of the long ridge formed by the Căpătânii Mountains (forming a succession of peaks - such as Ursu $2124 \mathrm{~m}$, Zmeuret 1979m, Lespezi 1822m, Netedul 1822m, Preota 1954m, Căprăreasa 


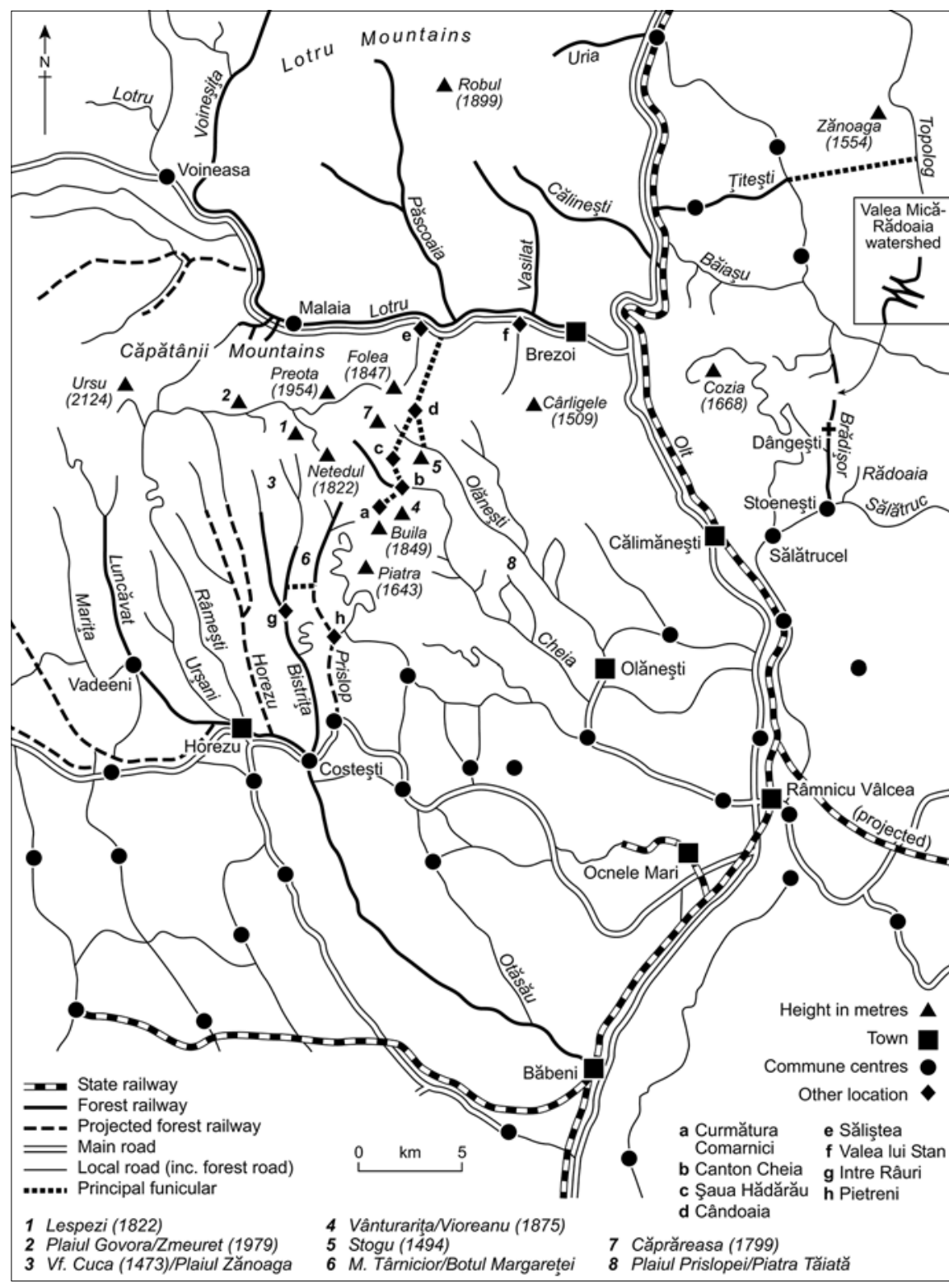

Figure 3 Forest railways in Vâlcea county

$1799 \mathrm{~m}$ and Folea $1847 \mathrm{~m}$ - above high surfaces ('plaiuri') where forest gave way to high mountain pastures: traditional transhumance areas with the grazing station (stâna) a common feature. The area was first penetrated by a $15 \mathrm{~km}$ funicular system from Gura Păscoaiei on the Lotru near Săliştea on the Lotru floating system that reached the main watershed at Cândoaia $1486 \mathrm{~m}$, with intermediate stations at the secondary watersheds of Suhăroasa $863 \mathrm{~m}$ and Cioroiu $1,283 \mathrm{~m}$. It then crossed the Olăneşti valley to Şaua Hădărău via the intermediate station of Stâna Măguruli near Folea mountain before descending to Canton Cheia (above the gorge) to end at Curmâtura Comarnici near the spruce forests of the Buila-Scânteia area. Steam power was provided by a $12 \mathrm{ohp} \mathrm{Lanz} \mathrm{en-}$ gine moved 50 'vagoneți' 240m apart each carrying 60o-70okg of wood. In the communist period this system was developed by four kilometres of forest railway along the Căprăreasa headwater of the Cheia above Canton Cheia with a small diesel lo- comotive hauling four wagons. There was also a connection with the Olânești valley though a branch on the funicular from Cândoaia to La Rampa.

Meanwhile, as regards the approaches from the Olt valley south of Râmnicu Vâlcea, the landscape could be likened to a sheet of corrugated iron with a succession of north-south trending valleys with steep ridges between them that were particularly mountainous in the case of the ridge between the Prislop and Cheia valleys with a chain of mountains like Piatra 1643m, Buila $1849 \mathrm{~m}$ and Vânturarița-Vioreanu $1875 \mathrm{~m}$. Elsewhere the watersheds were typically steep and densely wooded, but giving way to tracks heading towards the Căpătânii summits: Plaiul Prislopei/Piatra Tăiată between the Cheia and Olăneşti valleys, M.Târnicior/Botul Margareței between the Prislop (Costeşti) valley and the Bistrița, and Plaiul Govora between the Bistrița headwaters and its tributary the Gurgiu. The valley profiles themselves were steep in places - with gorges on the Bistrița at Arno- ta and on the Cheia below Stogu mountain $(1494 \mathrm{~m})$ as they graded upwards towards the 'plaiuri'. A new era in forest transport began when the state logging company CAPS decided to locate a sawmill at Arnota in 1934 where a 1oohp steam engine worked two saws (for beech and fir) and 35 workers produced $45 \mathrm{cu} . \mathrm{m}$ of planks daily. The decision evidently arose from a large 4.5th.ha forest concession, the water power potential of the Bistrița where a small hydropower station was built (operating until 1958 when a mains supply arrived) and the feasibility of road transport by lorry to the main railway line at Băbeni. A narrow gauge railway was extended with some difficulty through the Bistrița gorge in 1935 and later extended during the Second World War to Băbeni where the sawmill was relocated in 1953. The original railway has been described a veritable work of engineering art (Bondoc 2002, p.291) with 5om radius curves and gradients of 1 in 30 to negotiate the steep and winding Bistrița gorge, not to mention some $1,500 \mathrm{~m}$ of reinforcement to protect the track from erosion.

But in the 1950s the railway was extended to the adjacent Prislop valley which was too steep above Pietreni - with a difference in level of $170 \mathrm{~m}$ over just three kilometres: a gradient of 1 in 17.6 - for the planned railway to be built from Costești. The solution was a separate $750 \mathrm{~mm}$ line running for six kilometres along this valley and connected with the Bistrița near the confluence of Între Râuri. While the 'main line' was eventually equipped with standard Reşița o-8 oT 15ohp locomotives, working two trains of 30-35 wagons of the 'tip truc extensibili' (i.e. with the tree stems strapped to bogies so that any length could be accommodated), the extension was worked by gravity (the loaded wagons controlled by handbrakes) with animals to haul the empty wagons back up the valley until a 'locotractor' with a Soviet $65 \mathrm{hp}$ motor was introduced in 1953 and finally a 5ohp Reşița locomotive in 1955 (assembled from pieces transported by funicular). This system operated for 15 years hauling trains consisting of four wagons of tree stems ('buşteni') and two carrying 'lemne debitate' (i.e. firewood and other material for sale). By 1970, forest roads put the whole system out of business although the section below Arnota was retained for the transport of limestone for the chemical industry (already noted) and continues to operate on this basis today using diesel locomotives. But in the 1950s there was also a plan to use the Bistrița railway as the base from which other valleys could be penetrated: not only the Prislop to the east (giving access to the southwestern edge of the Buila ridge) but also a series of valleys to the west: Horezu, Luncavăț, Cerna and Olteț. But the plan was only partially realised. A line to 
the Luncavăț valley, extending north of Vaideeni, was built as planned but the other proposals were abandoned given the road building policy adopted in 1958 .

Another early post-war project concerned the timber on the northeastern side of the Cozia massif. Steep valley profiles prevented construction directly from the Olt so a start was made at Stoeneşti in the Sălătrucel valley. The line followed the tributary Brădisor valley through Dângeşti village to the east of Cozia mountain and crossed the watershed into the Băiaşu catchment at the $738 \mathrm{~m}$ Gresiilor Saddle (below Cumpăna mountain) to access the Groşilor forest below. This inevitably contravened the guiding principle that loaded wagons should move downhill wherever possible and although bulk was reduced by locating the Casian sawmill within the forest to process part of the production close to the source, it was still necessary to take all loaded wagons - sawn timber, unoprocessed stems or 'buşteni' and firewood in meter lengths ('metri') - up to the summit in small groups of four before a full train could be marshalled. More complex however was the system for crossing a lower but steeper watershed at $700 \mathrm{~m}$ between the upper Brădisor (Valea Mică) and the parallel Rădoaia valley that also drained to the Sălătrucel and where the main control for the line was located. Here a zig-zag layout was installed by CFF chief engineer Nicolae Armăsescu which meant that the locomotive had to reverse three times. Further to the north, a railway was built from the Olt at Cornet through the Titeşti valley to connect with a funicular extending to the upper Topolog via the watershed south of Zănoage mountain (1554m), operating until 1970. It seems that after serious fire damage the funicular system extended all the way to the Olt valley. There was also a $15 \mathrm{~km}$ line in the Călineşti (surviving until 1965) with a rack system to reach the slopes of Robul mountain at Izvoru Frumos and another of seven kilometres extending along the Uria valley from Câineni, though it did not operate after World War Two. Road building quickly brought an end to the forest railways during the 1960 s and the fact that none survived into the later communist years is an indication of the difficulties of operation and maintenance. The roads themselves were works of art even in the main valleys like the Prislop north of Pietreni which had defied the railway builders. Figure 3 shows the winding roads towards the Buila ridge while a tunnel was necessary under Stogu mountain to reach the uppermost section of the Cheia. In places the valley roads went rightacross the Căpătânii: one road from Hore- zu reached the 'plai' from the Râmeşti valley and crossed into the Malaia valley of the Lotru catchment while throwing off pastoral roads that followed the main watershed. Another crossing was made from the Olteț across the summit to Patrimanu Lake in the Latorița valley.

\section{Conclusion}

The special circumstances of the 1950s, when Romania was forced into the Soviet mode of communist dictatorship and central planning, with the heavy constraint of Moscow's war reparation demands, necessarily placed heavy reliance on steam railways with ambitious plans for network expansion to continue the rhythm of growth from the 1940s. On the state railway events were quickly overtaken by the 'new course' of 1953, but the forest railways continued to expand on a remarkable scale until a switch to road transport was signalled in 1958. In the 'middle period' it is evident that new transport technology served to increase the role of other modes (airways for inter-city links with roads as local feeders) so that for railways the focus moved to capacity increases on the existing system to serve a set of expanding regional centres on which the bulk of the investment was allocated - rather than create new routes. The railways thus passed from a phase of extensive development to one of intensive growth. But curiously, given the idiosyncratic approach taken by the Ceauşescu régime in the 1980s, a policy of self-sufficiency and energy conservation switched the focus back to the railways and new construction accelerated. There was no longterm plan but the CFR were evidently able to produce a 'wish list' (including both old and new ideas) and the regional railway construction companies were put to work on them, while also continuing to dealing with widening and electrification work. And although the pendulum has swung again since 1989 this latest era of expansionism continues to influence Romanian transport planning over its current preoccupation with the European corridors.

\section{References}

Barbacioru, C., 1983. Raționalitate în reartizarea teritorială a forțelor de producție: studiu comparative pe exemplul județelor din Oltenia (Craiova: Scrisul Românesc).

Beier, R.,Hufnagel, H. 1993. Wälder und Dampf II: Bilder aus vergangenen Tagen der CFF (Gablitz: Otto Novacek).

Bondoc, D. 2002. Coteşti-Vâlcea: 45 secole de istorie - monografie (Râmnicu Vâlcea: Editura Offsetcolor)
Groza, O., Muntele, I. 1998. 'L'efficacité du reseau ferroviaire et l'accessibilité territoriale en Roumanie' Revue Roumaine de Géographie 42, 15-28.

Iacob, G. 1987. 'Potențialul forestier al bazinului hidrografic Lăpuş şi valorificarea lui', Lucrărilor Seminarului Geografic Dimitrie Cantemir Iaşi 8, 277-84.

Iordănescu, D., Georgescu, D. 1986. Construcții pentru transporturi în România (Bucharest: Centrala de Construcții Căi Ferate) 2 vols.

Moga, N., Stanciu, G. 2002. Voineasa: paradigma identității (Resita: Editura Timpul),

Moldovan, R. 1964. 'Dezvoltarea economică a regiunilor relative rămase în urmă în trecut': V. Malinchi ed., Industria româniei 1944-1964 (Bucharest: Editura Academiei RPR) 135-62.

Muică, N., Turnock, D. 2003. The railway age on the Carpathian forests: a study of Romania', Geographica Pannonica 7, 9-20.

Nimigeanu, V. 1981. 'Căile de comunicație şi transporturile din Podişul Moldovei', Lucrările Seminarului Geografic Dimitrie Cantemir Iaşi 2, 201-9.

Paptănase, E., Vornicescu, F. 1964. Atlas geographic (Bucharest: Editura Didactică şi Pedagogică).

Peaha, M., 1965. 'Contribuții la studiul posibilităților de construire căii ferate Curtea de Argeş-Râmnicu Vâlcea', Comunicăre de Geografie 3, 287-300.

Rădoi. A. 1954. 'Geografia transporturilor şi a căilor de comunicație din RPR', Natura 6(1), 3-23.

Reichel, R., Hufnagel, H. 1990. Wälder und Dampf: 10ookm auf den Waldbahnen Rumäniens (Gablitz: Otto Novacek).

Soran, E., 1953. 'Maretul program al dezvoltării căilor ferate', Probleme Economice 6(4), 77-99.

Turnock, D. 1999. Railways and economic development in Romania before 1918 (Leicester: University of Leicester, Faculty of Social Sciences Discussion Papers in Geography G99/1).

Turnock, D. 2004. Railway network development in inter-war Romania: economic and strategic motives, Geografica Pannonica 8, 16-24

Velcea, I., Cucu, V. 1956. 'Geografia economică a raionului Novaci', Probleme de Geografie 3, 271-88.

\section{Acknowledgement}

The assistance of Serban Lacrițeanu (Bucharest) and Gheorghe Ploaie (Râmnicu Vâlcea) is gratefully acknowledged. 